\title{
Understanding Causation in Private Securities Lawsuits: Building on Amgen
}

James D. Cox*

I. INTRODUCTION ................................................. 1719

II. BASIC UNVARNISHED ............................................. 1722

III. THE POST-BASIC MUdDLE ........................................... 1725

A. Inability to Test the Thesis .............................. 1727

B. $\quad$ Misapplied Theory and Data........................... 1731

C. $\quad$ Divining Efficiency and Fraud from

Stock Prices ................................................. 1734

IV. Reliance: Genesis, MEANing, AND FunCTION ............. 1737

A. The Common-Law Analogy................................. 1737

B. $\quad$ Causation Is Context Specific ............................ 1740

C. Causation in Collective Decisionmaking .............. 1742

V. AMGEN'S CLARIFICATION....................................... 1744

VI. SCALIA'S NEAR HIT .................................................. 1747

VII. CONCLUSION: MATCHING THE APPROACH WITH TODAY'S

MARKETS .................................................................. 1751

\section{INTRODUCTION}

The securities antifraud provision is a bastard. It has no indisputable parentage; its existence is attributed to a federal statute, but its features are borrowed from state law, a body of law that the

\footnotetext{
* Brainerd Currie Professor of Law, Duke University. The Author is grateful for the suggestions of Professors Jill Fisch and Hillary Sale, as well as the participants in the 19th Annual Conference of the Institute for Law and Economic Policy and 15th Annual Vanderbilt Law and Business Program. The author benefited from the research assistance of Messrs. Robert Blaney, Ryan Klafen and Derek Magnuson.
} 
enacting Congress presumably believed was inadequate. ${ }^{1}$ Why would Congress borrow from state law that it considered deficient? Even though the antifraud provision has come of age largely through judicial construction similar to the laudatory process that underlies our common law, critics attack the antifraud provision like no comparable common-law development. To many scholars, private antifraud suits are not viewed as a net benefit, but as a menace. ${ }^{2}$ As a consequence, the fate of future suits under the antifraud provision always appears to hang in the balance of the next Supreme Court decision. The uncertainty is because most Supreme Court decisions construing the statute have largely restricted the scope of the antifraud provision; over the years, the Supreme Court has limited the antifraud private cause of action through decisions regarding who has standing to sue, ${ }^{3}$ what constitutes culpable conduct, ${ }^{4}$ and who is responsible for fraudulent conduct. ${ }^{5}$ On each of these issues, the Supreme Court has restrained the scope of the private action. Following Amgen Inc. $v$. Connecticut Retirement Plans and Trust Funds, ${ }^{6}$ the vultures once again circle the antifraud provision.

Lurking in the shadows is a potentially mortal blow to the securities class action because it appears the Supreme Court is poised

1. See, e.g., Basic Inc. v. Levinson, 485 U.S. 224, 244 n.22 (1987) (observing that actions under Rule 10b-5 are "designed to add to the protections provided investors by the common law").

2. See, e.g., William W. Bratton \& Michael L. Wachter, The Political Economy of Fraud on the Market, 160 U. PA. L. REV. 69, 161-63 (2011) (arguing that SEC enforcement is less costly and more productive than private enforcement); Joseph A. Grundfest, Why Disimply, 108 HARV. L. REV. 727, 746-48 (1995) (arguing that the SEC should exercise its rulemaking authority to address features of Rule 10b-5 that lead to abusive litigation practices); Amanda M. Rose, Reforming Securities Litigation Reform: Restructuring the Relationship Between Public and Private Enforcement of Rule 10b-5, 108 CoLUM. L. REV. 1301, 1354-58 (2008) (proposing that the SEC serve a clearing function for the conduct of private securities class actions).

3. See Blue Chip Stamps v. Manor Drug Stores, 421 U.S. 723, 731, 739-41 (1975) (imposing a rigid requirement that a private litigant must be an actual purchaser or seller in connection with the fraud, reasoning that otherwise, the cause of action would invite costly and "vexatious" litigation).

4. See Santa Fe Indus. v. Green, 430 U.S. 462, 474-80 (1977) (holding that antifraud provision proscribes material misrepresentation or manipulation, not breaches of fiduciary duty or unfair conduct); Ernst \& Ernst v. Hochfelder, 425 U.S. 185, 201-05 (1976) (holding that provision only reaches misrepresentations committed with scienter); see also Morrison v. Nat'l Austl. Bank, Ltd., 130 S. Ct. 2869, 2881 (2010) (holding that antifraud provision does not apply extraterritorially).

5. $\quad$ See Janus Capital Grp., Inc. v. First Derivative Traders, 131 S. Ct. 2296, 2302 (2011) (holding that responsibility for material misrepresentation extends only to those who had ultimate authority over the statement, including its content and whether and how the statement would be released); Cent. Bank of Denver v. First Interstate Bank of Denver, 511 U.S. 164, 175-77 (1994) (holding that those who merely aid and abet another's violation are not liable under the antifraud provision).

6. $\quad 133$ S. Ct. $1184,1184(2013)$. 
to address an aspect of causation that strikes at the heart of such suits - the ability of injured investors to aggregate their claims on the theory that the defendant's misrepresentation constituted fraud on the market. Unlike the other significant elements of the antifraud private cause of action, Supreme Court precedent on causation is something of a mixed bag. While there are Supreme Court precedents addressing causation that favor plaintiffs, ${ }^{7}$ the more recent forays into this subject suggest a more conservative tilt. ${ }^{8}$ That trend, and the overall unwelcome reception the antifraud provision has received on other issues, may just document the belief that with respect to the antifraud provision, once a bastard always a bastard. This denouncement need hardly be the case. This Article takes a more hopeful course by clarifying the role that causation should play in private securities litigation and showing how that objective can be achieved within current Supreme Court formulations of causation.

Most investors who believe they have been defrauded in connection with trades on a market, like those in Amgen, cannot practically pursue their claims other than through a class action. Within this context, a court's decisions both to certify the class and to deny a motion to dismiss define the ultimate fate of the suit. For the risk-averse defendant who loses each of these skirmishes, the optimal strategy is to settle the suit. In contrast, for investors in such suits, class certification is not just one of the hurdles that must be successfully vaulted to obtain compensation for damages caused by the misrepresentation; it frequently is the highest of the hurdles. Failing certification, there is no effective means for investors to assert their claims; it is only through aggregation of claims that a suit is practicable since most claimants' losses are not large enough to justify the expense of their individual prosecution. Requiring that investors establish the misrepresentation's materiality as a precondition to class certification

7. Plaintiffs have enjoyed some success on the scope of materiality. See, e.g., Matrixx Initiatives, Inc. v. Siracusano, 131 S. Ct. 1309, 1321 (2011) (holding materiality of possible side effects of a pharmaceutical company's major product can exist even without statistically significant evidence of a causal link); Va. Bankshares, Inc. v. Sandberg, 501 U.S. 1083, 1095-96 (1991) (holding opinion statements that are inconsistent with objective evidence between the defendant are facts); see also Merck \& Co. v. Reynolds, 559 U.S. 633, 652 (2010) (holding statute of limitations does not begin to run until a plaintiff does discover, or a reasonably diligent plaintiff could have discovered, facts constituting a violation).

8. See, e.g., Janus Capital, $131 \mathrm{~S}$. Ct. at 2302-03 (interpreting scope of primary participant narrowly so it reaches only one with ultimate control of a false statement's dissemination); Stoneridge Inv. Partners, LLC v. Scientific-Atlanta, Inc., 552 U.S. 148, 152-53 (2008) (rejecting scheme liability with the result that those who actively conspire to assist another in issuing false financial statements are not primary participants); Dura Pharms., Inc. v. Broudo, 544 U.S. 336, 345-46 (2005) (imposing a requirement that complaint must allege facts supporting the claim that misrepresentation caused the investor to suffer an economic loss). 
inserts another point of friction into the investor's access to the settlement arena. For defendants, this requirement is one more means to avoid settling a suit.

Therefore, the sine qua non for any securities class action is successfully invoking the fraud-on-the-market approach to establishing causation. Fraud on the market was embraced by the Supreme Court in a 4 to 2 decision in Basic Inc. $v$. Levinson, ${ }^{9}$ a case that appears destined to be revisited, likely soon. ${ }^{10}$ This Article argues that lower courts have misunderstood Basic. The prevailing misunderstanding is attributable to the Basic court's failure to comprehend the foundations of its own reasoning: the meaning and implications of the efficient market hypothesis.

Because Supreme Court precedent is difficult to reverse, this Article does not seek to correct Basic. Instead, this Article counsels reorientation, not correction. More specifically, the Author argues that the future course should be set by the majority opinion and Scalia's dissenting opinion in Amgen, as they more clearly illuminate the best path for future securities class actions. When fraud on the market, or any other dimension of causation in private securities law claims, comes before the Court, Amgen should provide the resolving foundation and framework, not Basic.

\section{BASIC UNVARNISHED}

The Court first recognized fraud on the market in Basic Inc. $v$. Levinson, where on three occasions over a thirteen-month period Basic publicly disclaimed any knowledge of a company development that would explain the increased trading in its stock. In fact, Basic was engaged in negotiations for its own acquisition. ${ }^{11}$ When Basic announced it would merge with Combustion Engineering, its stock soared. Disappointed investors who sold Basic's shares in the interval between the company's first denial and the merger announcement brought a class action alleging the misstatements were materially misleading because Basic had been locked in discussions and negotiations with Combustion during the thirteen-month period. Their suit would ultimately establish the parameters within which the securities class action suit survives, if only barely at times.

9. 485 U.S. $224,249-50$ (1988).

10. In Amgen, Justice Alito openly invited reconsideration of fraud on the market. $133 \mathrm{~S}$. Ct. at 1204 (Alito J., concurring). In a portion of Justice Thomas's dissent joined by Justices Kennedy and Scalia, Justice Thomas labels Basic itself as "questionable." Id. at 1208 n.4 (Thomas J., dissenting).

11. Basic, 485 U.S. at 227. 
In addition to holding that the materiality of speculative information should be the product of the event's magnitude and the probability of its occurrence, ${ }^{12}$ the Court upheld fraud on the market. The Court held reliance was required for private suits under the antifraud provision. However, the slight majority of four of the participating Justices held that investors are presumed to rely on the security's price reflected in all publicly available information in welldeveloped markets. ${ }^{13}$

While clearly holding "that reliance is an element of a Rule 10b5 cause of action" 14 and explaining that "[r]eliance provides the requisite causal connection between a defendant's misrepresentation and a plaintiff's injury," 15 Basic provides an important qualification to these conclusions by observing that " $[\mathrm{t}]$ here is . . more than one way to demonstrate the causal connection."16 Basic references the Court's earlier decisions in Affiliated Ute Citizens $v$. United States, viewing it as a decision in which reliance was dispensed with (rather than, as argued below, being based on an array of facts from which reliance was easily deduced), as well as Mills v. Electric Auto-Lite Co. (where the requisite causation was met by the necessity of the proxy solicitation, not the particular defect in the proxy materials, being essential to consummating the alleged harmful transaction). ${ }^{17}$ Blackmun's majority opinion in Basic holds that reliance was satisfied by allegations that the investors relied on the integrity of the price reflected in the market. Notably, only once did the Court in Basic expressly reference the concept of an "efficient market," and then only when quoting the approach taken by the court of appeals below. ${ }^{18}$ More frequently, the Court used the less technical adjectives "developed,"19 "welldeveloped," 20 or "modern" 21 when referring to securities markets on which investors presumably rely for securities' prices that reflect publicly available information:

The fraud on the market theory is based on the hypothesis that, in an open and developed securities market, the price of a company's stock is determined by the available material information regarding the company and its business. . . Misleading statements will therefore defraud purchasers of stock even if the purchasers do not directly rely on the

12. Id. at 238-39 (citing SEC v. Tex. Gulf Sulphur Co., 401 F.2d 833, 849 (2d Cir. 1968)).

13. Id. at $246-47$.

14. Id. at 243 .

15. Id.

16. Id.

17. Id. at 243 (citing Mills v. Elec. Auto-Lite Co., 396 U.S. 375, 384-85 (1970)).

18. Id. at $248 \&$ n. 27 .

19. Id. at 241, 244 (quoting Peil v. Speiser, 806 F.2d 1154, 1160-61 (3d Cir. 1986)).

20. Id. at 246 .

21. Id. at 243 . 
misstatements. . . . The causal connection between the defendants' fraud and the plaintiffs' purchase of stock in such a case is no less significant than in a case of direct reliance on misrepresentations. ${ }^{22}$

Justice Blackmun further supported the plurality opinion by contrasting personal, face-to-face decisionmaking with impersonal market transactions:

\begin{abstract}
In face-to-face transactions, the inquiry into an investor's reliance upon information is into the subjective pricing of that information by that investor. With the presence of a market, the market is interposed between seller and buyer and, ideally, transmits information to the investor in the processed form of a market price. Thus the market is performing a substantial part of the valuation process performed by the investor in a faceto-face transaction. The market is acting as the unpaid agent of the investor, informing him that given all the information available to it, the value of the stock is worth the market price. ${ }^{23}$
\end{abstract}

The Court approved the presumption used by the lower courts, which stated that "persons who had traded Basic shares had done so in reliance on the integrity of the price set by the market." ${ }^{44}$ Note that the presumed reliance is not on any particular information that may have impacted a security's price but on the general belief that financially significant information may impact the security's price. Importantly, the Court reached this conclusion because it found a strong congressional objective to facilitate investor reliance on the "integrity" of securities markets. It further supported its conclusion regarding how stock prices are formed in well-developed markets. ${ }^{25}$ While lower court decisions subsequent to Basic consistently condition its application on a finding that the market in question is an "efficient" one, Basic referred more generally to "developed," "well-developed," or "modern" markets. It did not invoke the "efficient market" moniker used by economists to describe the hypothesized performance of capital markets. Importantly,

22. Id. at 241-42 (quoting Peil, 806 F.2d at 1160-61). The reasoning adopted in Basic was more fully developed earlier in a leading fraud-on-the-market case, Blackie v. Barrack, 524 F.2d 891 (9th Cir. 1975). Blackie concluded that:

[The investor] relies generally on the supposition that the market price is validly set and that no unsuspected manipulation has artificially inflated the price, and thus indirectly on the truth of the representations underlying the stock price whether he is aware of it or not, the price he pays reflects material misrepresentations.

$I d$. at 907 . The court further supported its position by concluding the approach was consistent with the antifraud statute to "foster an expectation that securities markets are free from fraud an expectation on which purchasers should be able to rely." Id.; see also Peil, 806 F.2d at 1161 ("In an open and developed market, the dissemination of material misrepresentations or withholding of material information typically affects the price of the stock, and purchasers generally rely on the price of the stock as a reflection of its value."). Basic also held that fraud on the market was consistent with Congress's intent. See 485 U.S. at 245-46.

23. 485 U.S. at 244 (quoting In re LTV Sec. Litig., 88 F.R.D. 134, 143 (N.D. Tex. 1980)).

24. Id. at 245 .

25. Id. at 246 . 
Basic anchors its approach on the grounds that historically justify courts' reliance on presumptions, namely "fairness, public policy, and probability, as well as judicial economy." 26 To further support presuming investor reliance, Basic invoked the contemporary empirical evidence of stock-price formation and related commentary on the implications of that literature for the conduct of securities class actions as support with respect to the probability component of the factors considered to invoke resort to a presumption of reliance. ${ }^{27}$

\section{The Post-BASIC MUdDLE}

Post-Basic lower court decisions have considerably narrowed its holding regarding fraud on the market by seeking evidence of speed or accuracy of price formation as a predicate for certifying class actions on the basis of fraud on the market. ${ }^{28}$ With some consistency, for example, lower courts have withheld class certification on the basis of fraud on the market where there is evidence that a security does not reflect all public information. In In re PolyMedica Corp. Securities Litigation, the First Circuit reversed the district court's certification of the class when it found that the defendant shares were traded in a market where the security's price rapidly reflects only most material information. ${ }^{29}$ The First Circuit vacated the certification and remanded the case so that the district court could consider certification pursuant to the First Circuit's standard. ${ }^{30}$ The panel reasoned that the presumption of investor reliance is valid only when the market is efficient. The panel defined market efficiency as when the market rapidly reflects all information relevant to the company's value. ${ }^{31}$

PolyMedica also concluded that efficiency does not require proof that the particular security's price, after reflecting "all" public

26. Id. at 245 .

27. Id. at $246 \mathrm{n} .24$ (citing to authorities reviewing studies bearing on the efficient market hypothesis).

28. See, e.g., Unger v. Amedisys, Inc., 401 F.3d 316, 322 (5th Cir. 2005). Unger denied class certification for a suit involving securities traded in the Over-the-Counter Bulletin Board because small-capitalization issuer traded in a less-organized market was not considered efficient. Id. ("[T]he available material information concerning the stock translates into an effect on the market price and supports a class-wide presumption of reliance."). Suits have fared no better for shares traded on the NASDAQ National Market. See Bell v. Ascendant Solutions, Inc., 422 F.3d 307, 315 (5th Cir. 2005) (emphasizing turnover as a percentage of outstanding shares, not the particular exchange, when assessing whether shares were efficiently traded).

29. 432 F.3d 1, 10-11 (1st Cir. 2005).

30. Id. at 19 .

31. Id. at 14 . 
information, is accurate. ${ }^{32}$ It is sufficient that the price responds rapidly to financially significant information. This is commonly referred to as the market being "informationally efficient." Because prices can vary from the securities' intrinsic value - a matter on which investors likely hold different beliefs-investors in such a market can reasonably believe a security is still worthy of being purchased or sold. Investors can reasonably believe the market has not correctly valued the security notwithstanding the richness of public information about the company's future. That is, PolyMedica envisions that even in an efficient market, investors can garner positive returns on the basis of publicly available information.

PolyMedica and the numerous other decisions that share its holding are paradoxical. ${ }^{33}$ Pursuant to this approach, investor reliance is reasonable and hence presumed for securities whose prices quickly respond to financially significant information. At the same time, these courts do not require so-called fundamental efficiency (i.e., that the resulting price reflects the security's intrinsic value). Essentially, these courts recognize that all investors do not assume the current trustworthiness of the price vis-à-vis the shares' probable intrinsic value. Thus, notwithstanding the public availability of information, reasonable investors in such a market can believe that the price may not reflect the security's intrinsic value, which leads to opportunities for returns. ${ }^{34}$ On the one hand, this position seems entirely correct since

32. The opinion takes great care to distinguish informational efficiency from fundamental efficiency where the former refers to the market's response to financially significant information, and the latter refers to a market where the ultimate response is an accurate pricing of the security. Id. at $14-17$.

33. See, e.g., Gariety v. Grant Thornton, LLP, 368 F.3d 356, 368 (4th Cir. 2004) (“[A]n efficient market . . adjusts rapidly to reflect all new information.”); Greenberg v. Crossroads Sys., Inc., 364 F.3d 657, 661 n.6 (5th Cir. 2004) ("[I]n an efficient market, it is assumed that all public information concerning a company is known to the market and reflected in the market price of the company's stock.”); No. 84 Emp'r-Teamster Joint Council Pension Trust Fund v. Am. W. Holding Corp., 320 F.3d 920, 947 (9th Cir. 2003) ("[I]n a modern and efficient securities market, the market price of a stock incorporates all available public information.”); GFL Advantage Fund, Ltd. v. Colkitt, 272 F.3d 189, 208 (3d Cir. 2001) (stating that in an efficient marketplace, "stock prices reflect all available relevant information about the stock's economic value"); Joseph v. Wiles, 223 F.3d 1155, 1163 n.2 (10th Cir. 2000) ("[I]n an open, efficient, and developed market, where millions of shares are traded daily, the investor must rely on the market to perform a valuation process which incorporates all publicly available information, including misinformation.”); Kowal v. MCI Commc'ns Corp., 16 F.3d 1271, 1276 n.1 (D.C. Cir. 1994) (“[I]n an efficient securities market all publicly available information regarding a company's prospects has been reflected in its shares' prices.”); Freeman v. Laventhol \& Horwath, 915 F.2d 193, 198 (6th Cir. 1990) (“[T] he price of an actively traded security in an open, well-developed, and efficient market reflects all the available information about the value of a company.").

34. See generally Sanford J. Grossman \& Joseph E. Stiglitz, Information and Competitive Price Systems, 66 AM. ECON. REV. 246 (1976) (arguing that because investors have quite different levels of information, it is not reasonable to assume that at any point in time the security's price 
financial theorists all concur that investors have heterogeneous expectations. Moreover, arbitrage is unlikely to eliminate material price differences that exist in light of such investor heterogeneity. On the other hand, if fraud on the market is only applied where investors are assumed to be unable to earn an above-average return based on public information, the courts appear to be invoking a different notion of market efficiency than is defensible under contemporary views of the hypothesis.

Courts should step back from the rhetoric of market efficiency and instead observe what appears to be implicit in the holdings of cases like PolyMedica: investors believe that market-determined prices are noisy and inaccurate rather than a perfect reflection of all information. Therefore, market pricing is not perfect vis-à-vis the investor's assessment of the security's return possibilities. If these are indeed the features of an efficient market, then why should courts limit fraud on the market to such an elite subset of publicly traded securities? That is, if evidence of accuracy in pricing is not a condition for fraud on the market-so that fraud on the market is applicable where prices are noisy-there can be little justification for the courts to limit fraud on the market to large-capitalization, publicly traded firms.

\section{A. Inability to Test the Thesis}

To untangle the post-Basic morass, one must begin with the courts' understanding of market efficiency. At the core of the lower courts' interpretation of Basic is the belief that markets can be separated by the court's notion of efficiency. First, the lower courts assume that, investors in markets believed to be efficient rely on the security's price to accurately reflect truthful information, whereas courts believe that investors in inefficient markets cannot be assumed to so rely. Second, and implicit in the prior statement, courts assume that the security's price of any security that does not generally trade efficiently will not be affected by any release of information. Courts therefore conclude that investors cannot be presumed to rely on information of any type ever being reflected in the security's price. These are important assumptions; they not only artificially and unreasonably divide markets but also prevent any discrimination in assumptions regarding just how information impacts an individual security if that security is traded on a market that falls in the broadly

will perfectly reflect the information investors have; consequently, prices are not likely to transfer information from the informed to the less informed investors). 
defined inefficient category. Neither assumption is intuitively obvious, and both likely lack empirical support.

Because there are no reliable models for determining the "correct" price of a security, it is not possible to determine whether all information, or even some information, is fully and rapidly impounded into a security's price, such that an abnormal return would not be possible by investors based on such information. ${ }^{35}$ That is, the supposition underlying contemporary applications of fraud on the market is that investors in efficient markets believe that a security's price reflects publicly available information regardless of whether that information is accurate or misleading. Pursuant to this supposition, investors cannot earn an above-average return by trading purely on public information. Correlatively, according to contemporary interpretations of Basic, since securities traded in inefficient markets do not reflect all public information, investors do not rely on the marketpricing process as they would in an efficient market.

Determining whether markets reflect information so robustly requires knowing what the "correct" price should be in light of the information. On this point, models fail us. Moreover, investors harbor heterogeneous views on the appropriate price of a security in light of their common knowledge of the information about the security. With no reliable model identifying the "correct" price, how can we conclude that a particular security not only moved to that price upon release of the information, but did so rapidly? And, if investors disagree about what the "correct" price should be, which one of their multiple viewpoints is the correct "correct" price? Leading economists have long pointed out that the dichotomy between efficient and inefficient markets is neither workable nor justified. ${ }^{36}$ None of these points appear to support the

35. Alon Brav \& J.B. Heaton, Market Indeterminacy, 28 J. CoRP. L. 517, 521 (2003):

Market efficiency requires that an asset price fully and immediately reflect available information, such that no investor can earn abnormal expected returns by trading on the available information at the current price. In order to determine whether prices are efficient or not, we must be able to determine whether the current price reflects all available information and is "correct" such that no investor can invest at that price and expect to earn abnormal returns. That is, we need a model of "fundamental value" into which we put the "available information" and out of which we receive a price at which no abnormal expected returns are possible. If the current price is lower than the calculated price, then positive expected abnormal returns probably exist. If the current price is higher than the calculated price, then negative expected abnormal returns probably exist. In either case, we must be able to compare the current price to a predicted "correct" price to determine if the current price is efficient or not.

(footnote omitted).

36. Fischer Black, Noise, 41 J. FIN. 529 (1986); Lawrence H. Summers, Does the Stock Market Rationally Reflect Fundamental Values?, 41 J. Fin. 591 (1986). Joining the academics is one who has toiled long and well in markets, George Soros. George Soros, My Market Theory: Forget 
conclusion that investors do in fact rely on the market-pricing process to establish a price that represents the shares' intrinsic value. On the other hand, they likely do assume that security prices are not rigged or otherwise impacted by false information (i.e., they rely on the overall honesty of securities markets). But, do investors rely on some markets more than others, as the courts' binary view of markets-either efficient or inefficient-appears to assume?

There are multiple mechanisms that cause some security prices, on average, to be less volatile and to respond more rapidly than others. ${ }^{37}$ This does not suggest, however, that such a response means that the security is efficiently priced for the reasons examined above. It is not, therefore, possible to extrapolate from generalized findings of the security's responsiveness to information either that the particular security has been priced efficiently or that investors in that security placed their reliance on the security being so priced. Any such conclusion would be specious. ${ }^{38}$ If the reliance element is understood as an element of causation, then the view of Professors Macey, Miller, Mitchell, and Netter advanced three decades ago remains wise guidance today: the efficient-versus-inefficient distinction must give way to objective evidence. This evidence would most likely take the form of a well-designed event study measuring whether the alleged fraud produces a statistically significant effect on the security's price. By focusing on what can be empirically observed, judicial resources could be more appropriately directed to a finite inquiry rather than an amorphous, unsound, and irrelevant inquiry about whether a particular security was efficiently priced. ${ }^{39}$ Thus, reliance should be

Theories, WALL. ST. J., Jan. 8, 2001, at A33 (arguing that the theory regarding market efficiency distorts reality).

37. See, e.g., Brad M. Barber et al., The Fraud-on-the-Market Theory and the Indicators of Common Stocks Efficiency, 19 J. CoRP. L. 285 (1994) (stating that volume and number of analysts enhance speed of price change); Victor L. Bernard, Christine Botosan \& Gregory D. Phillips, Challenges to the Efficient Market Hypothesis: Limits to the Applicability of Fraud-on-the-Market Theory, 73 NEB. L. REV. 781 (1994) (examining factors likely to support efficient pricing of securities); Ronald J. Gilson \& Reinier H. Kraakman, The Mechanisms of Market Efficiency, 70 VA. L. REV. 549 (1984) (reasoning that relative burdens to access and to interpret information impacts both the likelihood of and speed at which stock prices respond to information; thus, whatever information is implicit in past stock prices can easily be accessed and therefore reflected in stock prices whereas private information by insiders is not easily accessed; thus, insiders enjoy an unerodible advantage, which is why there is no evidence of the so-called strong form of market efficiency).

38. Jonathan R. Macey et al., Lessons from Financial Economics: Materiality, Reliance, and Extending the Reach of Basic Inc. v. Levinson, 77 VA. L. REV. 1017, 1018 (1991).

39. See id. at 1021. 
presumed where there is reliable evidence of such a statistically significant effect. ${ }^{40}$

If there is a good deal of noise surrounding the pricing of largecapitalization firms' securities, which are closely followed by numerous analysts because the markets are heavily populated by institutional traders, why should fraud on the market not apply to other noisy markets? If investors rely on the integrity of the market-pricing mechanism for large-capitalization firms, what persuasive evidence suggests that they do not similarly rely for small firms, especially if the pricing process of both markets is guided by heterogeneous expectations regarding an individual security's value?

No doubt Basic and the fraud-on-the-market theory's greatest failing is due to their timing in the history of economics. Each occurred before economists fully developed important refinements and qualifications to the efficient market hypothesis. ${ }^{41}$ The hypothesis's prescriptions were likely biased because the nature of the announcements studied were of the type that tended to elicit a strong response (e.g., unexpected earnings, merger, or significant change in dividends). Moreover, the early studies examined the market response to financially significant announcements only within a brief window. ${ }^{42}$ Those studies did not examine whether, over some longer period, price formation is an ongoing, rather than rapid, process. Fraud-on-themarket courts, after accepting an early understanding of the

40. Macey et al. support focusing on the fraud's impact on the stock price by applying the same reasoning advanced in Basic:

An investor who buys or sells stock at the price set by the market does so in reliance on the integrity of that price. Because most publicly available information is reflected in market price, an investor's reliance on any public material misrepresentations, therefore, may be presumed for purposes of a Rule 10b-5 action.

Id. (quoting Basic Inc. v. Levinson, 485 U.S. 224, 247 (1988)) (footnote omitted). There is a strong caveat to requiring observed stock price before finding that a material misrepresentation impacted investors. The approach works well for the material misstatement of unexpected news but, as developed later, is poorly suited to the pure omission case or a misstatement case that confirms investor expectations. In these two instances, the observation should shift from the moment of the false utterance to when the corrective disclosure is made. At that time, a noticeable price correction corroborates an otherwise bald assertion of material omission or misstatement. These points are developed later.

41. See generally Lynn A. Stout, The Mechanisms of Market Inefficiency: An Introduction to the New Finance, 28 J. CORP. L. 635, 667-69 (2003) (reviewing qualifications linked to heterogeneous investor expectations, limits on arbitrage, and social-psychological biases that impact securities pricing).

42. See William H. Beaver, The Information Content of Annual Earnings Announcements, 6 J. ACCT. Res. 67, 70 (1968); Peter Lloyd Davies, Stock Prices and the Publication of Second-Hand Information, 51 J. Bus. 43, 46 (1978); Eugene F. Fama, The Adjustment of Stock Prices to New Information, 10 INT'L ECON. REV. 1, 4 (1969); Eugene F. Fama, The Behavior of Stock Market Prices, 38 J. Bus. 34, 45 (1965); Michael Firth, The Information Content of Large Investment Holdings, 30 J. FIN. 1265, 1269 (1975). 
hypothesis, have not refined that understanding with contemporary insights regarding how markets price securities. Today, there is less clarity regarding the prescriptive qualities of the efficient market hypothesis. It remains a hypothesis, but one that is greatly qualified.

\section{B. Misapplied Theory and Data}

Post-Basic decisions have developed an array of criteria to determine if the security that is the subject of the suit was traded in an efficient market and, hence, if fraud on the market is an available cause of action. The criteria focus on daily trading volume, the number of analysts following the security, the presence of institutional ownership, and even whether the issuer is eligible for certain regulatory dispensations the SEC makes available to larger capitalization issuers. ${ }^{43}$ The courts believe that when each criterion is present, a security is more likely to be priced efficiently.

In a classic article on understanding market efficiency, Professors Gilson and Kraakman insightfully make the point that whether information is impounded quickly in a security's price depends a good deal on a range of externalities related to the particular bit of information. ${ }^{44}$ In part they reason that it is the message and the medium, not the market itself, that explain efficient pricing. ${ }^{45}$ Thus, we might find that stock prices themselves convey very little new information about prospective price movements because the prices are easily and widely observed and, hence, their information content can be easily extrapolated. At the other extreme, a person in possession of

43. See, e.g., Binder v. Gillespie, 184 F.3d 1059, 1065 (9th Cir. 1999) (applying five factors to determine an efficient market: high weekly volume, number of security analysts that follow and report on stock, presence of marketmakers and arbitrageurs, eligibility to use SEC Form S-3, and cause-and-effect relationship between news events and immediate price response); Cammer v. Bloom, 711 F. Supp. 1264 (D.N.J. 1989) (using same factors). As developed later in this Article, the nature of the announcement can be expected to affect the relationship between the announcement and a stock-price reaction to that announcement. Thus, generalized observations of the efficiency of a security's normal pricing may be substantially qualified by the nature of the announcement itself. One study of efficiency, focused on quarterly report announcements, found that only two of the preceding factors appear relevant to relative efficiency in pricing securitiesvolume of trading and number of analysts for the security. See Barber et al., supra note 37, at 290 (finding that only volume of trade and number of analysts reporting on a stock accurately differentiated between efficient and inefficient stocks). For an early critique arguing that there is no reliable litmus test for determining ex ante whether a security trades in an efficient market, see Jonathan R. Macey, The Fraud on the Market Theory: Some Preliminary Issues, 74 CoRNELL L. REV. 923, 925 (1989) (discussing difficulties of determining whether securities trade in an efficient market).

44. See Gilson \& Kraakman, supra note 37, at 597-98 (noting externalities such as information costs have a significant impact on market efficiency).

45. See id. 
nonpublic information derives a significant advantage over others because the acquisition costs to noninsiders are so formidable. It is just too costly and time consuming for outsiders to acquire such nonpublic information. Occupying a large space between these two extremes is public information; not only is there some friction in accessing public information but the processing costs in many instances likely slow the reflection of that information in the security's price. We can expect that not all public information will be impounded in a security's price with the same alacrity, or perhaps with any quickness at all. That is, message as well as medium likely impacts the quickness with which a security's price reflects particular information. Therefore, a continuum likely exists regarding whether and how rapidly a security's price will reflect public information in which the nature of the information is as significant as other variables, such as the relative size of the security's issuer, number of analysts that follow it, and presence of arbitrageurs. Hence, even for a security traded in an efficient market, as in Amgen, we should expect some types of newly released information to impact the security's price more quickly than other types of information, notwithstanding the fact that each announcement is material.

Thus, even though a company's shares are traded on the Overthe-Counter Bulletin Board ("OTCBB"), we can reasonably expect that an unexpected announcement that the company secured a government contract that will quadruple earnings will cause a fairly rapid positive price response. It may well be the case that less dramatic news about that company may take longer to influence its price. There appears little reason to support the notion that slowness of stock-price reaction in the less dramatic announcement detracts from the trustworthiness of observing the stock's reaction to the unexpected government contract. Moreover, there appears to be no rational basis to categorically conclude that investors do not rely on stock prices to reflect dramatic announcements; therefore, the tenets underlying Basic's presumed reliance should hold at least in such instances. Furthermore, a clear implication of the Gilson and Kraakman externality hypothesis is that the world cannot easily be divided between markets that are consistently efficient and those that are not. Nonetheless, the lower courts' contemporary analysis holds that a fraud-on-the-market action is not available even if an OTCBB-traded company deceives its investors by falsely announcing a large government contract.

Equally disturbing is the serious disconnect between the lower courts' criteria for determining market efficiency and the efficient market literature. The intellectual bedrock supporting the efficient market hypothesis is the numerous event studies conducted in the 1970 s and 1980s that collectively reported on how quickly stock prices 
were observed, on a portfolio basis, to respond to various corporate announcements. ${ }^{46}$ The early stock-price studies clustered necessarily around the University of Chicago Center for Research in Security Prices database that provided stock prices, focusing on large, publicly traded firms. In this way, the investigators were similar to the person in the classic tale who was looking at night for his car keys, not where he had parked his car, but rather in the vicinity of the street lamp because there he could see. Also, since the initial empirical work focused on testing the validity of the efficient market hypothesis itself, the studies naturally concentrated on securities that were more likely to have conditions believed to lead to a security's efficient pricing. In doing so, researchers did not cull the database via the litmus test courts have developed regarding number of analysts, market capitalization or, for that matter, trading volume. They instead focused more broadly, using companies that were included in commonly used stock indexes such as the Dow Jones Industrial or Standard and Poor's 500. To be sure, larger firms, in terms of market capitalization and trading volume, coupled with the presence of institutional trading and a larger number of analysts likely cause the price reaction to be quicker. But as Gilson and Kraakmann observe, efficiency is not binary, but rather a continuum. ${ }^{47}$ And, more recent empirical studies do report on how, and how rapidly, price movements occur for over-the-counter securities, even those traded in the unregulated "Pink Sheet" market. ${ }^{48}$ Moreover, absent a compelling argument why the speed of price response should determine fraud on the market's application more than the ultimate price change itself, foreclosing the application of fraud on the market to instances in which the price response on average occurs faster is arbitrary. Certainly, the arbitrariness of focusing on hypothetical quickness is glaring when there is evidence that a defendant company's shares actually moved dramatically and quickly in response to a disclosure that is at the heart of the suit. Furthermore, there is no empirical

46. For this qualification to the early studies supporting the efficient market hypothesis, see Stout, supra note 41, at 653-57 (reasoning that early work focused on merger announcements and the like, which were not just significant, but also widely available in contrast to more regular announcements of corporate events).

47. Gilson \& Kraakman, supra note 37, at 565-66.

48. See Laura Frieder \& Jonathan Zittrain, Spam Works: Evidence from Stock Touts and Corresponding Market Activity 11-12 (Harvard Pub. Law, Working Paper No. 135, 2007), available at http://papers.ssrn.com/sol3/papers.cfm?abstract_id=920553 (reporting that trading activity increased from four percent to seventy percent on day announcement touting stock appeared); Kate Litvak, Summary Disclosure and the Efficiency of the OTC Market: Evidence from the Recent Pink Sheets Experiment 6-10 (Dec. 2008) (unpublished manuscript), available at http://ssrn.com/abstract=1443595 (observing return changes following announcement characterizing firms according to relative disclosure practices pursued). 
evidence that investors are less reliant on price or the noisiness of price across various markets.

\section{Divining Efficiency and Fraud from Stock Prices}

Post-Basic courts have confounded their refinement of the efficient market hypothesis through undue reliance on stock prices in resolving key elements of antifraud suits. They have developed the following sequence in the analysis to resolve otherwise-ticklish factual questions posed by the suit. Material information always moves a stock's price if the market is efficient. Hence, if there is no observable price reaction following an alleged misrepresentation, then either the information omitted or misstated was not material or the security is not efficiently traded. Thus, investor reliance cannot be presumed. ${ }^{49}$ As this Article will show, assessing market efficiency or materiality by observing stock-price changes is trickier than the courts assume.

In re Burlington Coat Factory Securities Litigation is the leading case holding that the absence of stock-price response equates to the information not being material. ${ }^{50}$ On September 20, 1994, Burlington's stock dropped nearly thirty percent when it announced that its fourthquarter and full-year results were below the levels of a year earlier. Investors claimed that Burlington earlier misled them by, among other representations, falsely reporting that 1993 earnings included $\$ 12.2$ million in extra sales due to that fiscal period having an extra week (i.e., fifty-third week). The necessary effect of this fiscal year phenomenon, according to the plaintiffs, was that 1994 would fall behind 1993 by about $\$ 12.2$ million in sales produced in the extra week, all things being equal. ${ }^{51}$ In July 1994, Burlington announced that the sales attributable to the extra week were $\$ 23.2$ million, nearly double the amount estimated earlier. Plaintiffs, investors who purchased shares during 1994, argued that investors calculated likely sales for 1994 by extrapolating from the erroneous announcement. ${ }^{52}$ Relying on the lower figure caused them to overestimate Burlington's likely performance in 1994 and thereby inflated the stock's price. Because no observable stock-price change occurred when the correct extra-week figure was

49. See generally Michael L. Hartzmark \& N. Nejat Seyhun, The Curious Incident of the Dog that Didn't Bark and Establishing Cause-and-Effect in Class Action Securities Litigation, 6 VA. L. \& BUS. REV. 415, 420-25 (2012) (reviewing multiple factors that can explain why there can be price movement without an accompanying newsworthy announcement and how a newsworthy announcement may not be accompanied by observable price movement).

50. 114 F.3d 1410, 1425 (3d Cir. 1997).

51. Id. at 1424 .

52. Id. 
released in July 1994, the Third Circuit dismissed the claim, reasoning that in an efficient market, if the correction of the earlier understatement of the extra week's sales was material, there would have been a noticeable change in Burlington's stock price. ${ }^{53}$

As seen, a company's announcement of unexpected good news (e.g., the receipt of a contract that will quadruple sales) can be expected to favorably impact a security's price in any market. Moreover, investors likely believe the security's price would be so impacted that the principal justification for Basic's embrace of fraud on the market would appear satisfied if the company falsely claimed to have received such a contract. Burlington Coat would also have concluded that the price movement upon release of the correct $\$ 23.2$ million extra-week figure, had such price change occurred, would support the assertion that the corrective announcement was material.

But changing the assumed facts of this simple illustration reveals the inherent narrowness and unreliability of determining either efficiency or materiality based on price response to the challenged announcement. For example, what might be the likely effect of announcing that the company had obtained a large contract if there were substantial expectations that the company would be the winning bidder? In this case, any expected favorable effect of the announcement on the stock's price could be due to the reduced uncertainty of whether the firm would prevail. If that uncertainty were small, the price reaction would be small, if not negligible. What, then, if the company fibbed in announcing it had obtained the contract, perhaps fearing repercussions if investor expectations were not met? Burlington Coat, placing unqualified emphasis on price change, would hold there was no material misrepresentation since the false announcement was not accompanied by an observable price change.

This raises the question whether the absence of market movement in Burlington Coat could be due to the fact that the corrected statement of the $\$ 23.2$ million benefit flowing from the extra week was consistent with investor expectations of what they might have

53. Id. at 1426-27. By contrast, in No.84 Employer-Teamsters Joint Council Pension Trust Fund v. America West Holdings Corp., the Ninth Circuit rejected a bright-line rule requiring an immediate market reaction to the disclosed information for it to be deemed material; the court reasoned that even an efficient market is "subject to distortions." 320 F.3d 920, 934 (9th Cir. 2003) (citing Basic Inc. v. Levinson, 485 U.S. 224 (1988)). In America West Holdings, there was no detectable market response to newspaper reports that the airline was skimping on maintenance and thereby reporting profitable operations, that it was the subject of an FAA safety investigation, or that the airline's own announcement that problems raised in the earlier news accounts had been fully addressed with a settlement with the FAA. See id. at 925-30. This is puzzling because a few months later the airline's stock declined six points when it announced that third quarter earnings declined due to unsatisfactory operational performance. See id. at 930. 
extrapolated from information that was available. This would not only explain the absence of any price change once the corrected figure was released but also justify dismissal of the case since announcement of the earlier, lower figure of $\$ 12.2$ million essentially harmed no one. Otherwise, the correct disclosure of $\$ 23.2$ million in extra sales could be expected to elicit a different reaction from investors, since this amount was not anticipated. ${ }^{54}$ In such instances, as well as in pure nondisclosure cases, evidence of stock-price change following the corrective announcement can substantiate the materiality assertion and address whether the market is informationally efficient.

The muddle following Basic is attributable to a fundamental flaw of Basic itself. The plurality opinion invoked a hypothesis that is descriptive of the market and then incorrectly used that hypothesis to describe investor behavior in response to the market. However, the hypothesis is not descriptive of investor behavior. There is nothing in the efficient market hypothesis that describes how investors behave; the hypothesis only suggests the consequences of their collective behavior. ${ }^{55}$ As such, the efficient market hypothesis is a non sequitur to explain probable investor reliance.

54. Eight years later, the Supreme Court essentially embraced the same reasoning by requiring evidence of loss causation for antifraud suits. See Dura Pharms., Inc. v. Broudo, 544 U.S. $336,347-48$ (2005). It may be better to view these cases not as instances of the alleged omitted or misstatement failing to cause an economic loss but rather evidence that the misrepresentation did not impact the security's price. This distinction flows naturally from the test of materiality not requiring proof that the alleged omission or misstatement changed the investors' decisions to trade or the price for the security.

55. Basic, in addition to lacking a solid theoretical foundation for its understanding of the efficient market hypothesis, and in limiting fraud on the market to securities that trade in "welldeveloped markets," also appears to be internally inconsistent with the reasoning used to reach these conclusions. The Court reasoned that in efficient markets "[a]n investor who buys or sells stock at the price set by the market does so in reliance on the integrity of that price." Basic, 485 U.S. at 247. Since reliance under this formulation moves from reliance on the particular statement made by the defendant to investor reliance on certain understood endowments of the market, why then would it not be appropriate for the defendant to argue that aggregation of the investors' claims was inappropriate because reliance by each investor on the integrity of the market's pricing of the security remains to be determined? This request should be denied only if the court were prepared to hold that such reliance is nonrebuttable. Instead, Basic recognizes the defendant's right to probe each investor's reliance, albeit the inquiry arises defensively. Thus, Basic's dicta of an investors' presumed reliance on the material misrepresentation being rebutted by proof the investor would have traded anyway appears to require individual inquiries into reliance. These inquiries may be a basis for concluding that common questions of law and fact do not predominate. Such an inquiry is unlikely to remove many investors from the class. Nonetheless, the process of identifying the few affected viewed at the moment of making the certification question is as daunting as inquiring whether each investor traded in the belief that market prices reflected only truthful publication or, for that matter, whether the individual investor read the allegedly false publication. In either case, hundreds of inquiries would destroy the efficiency of the class action procedure. 


\section{RELIANCE: GENESIS, MEANING, AND FUNCTION}

According to Basic, fraud on the market is all about reliance. But why is reliance an element of the antifraud suit? The Second Circuit solidified the incorporation of reliance into antifraud jurisprudence in List v. Fashion Park, Inc., ${ }^{56}$ reasoning that reliance is necessary "to certify that the conduct of the defendant actually caused the plaintiff's injury." 57 The court observed that failing to require reliance would eliminate "the principle of causation in fact." 58 After reviewing the extensive trial record, List held that the district court properly concluded that the plaintiffs would have sold their shares regardless of whether they had known of the omitted facts. ${ }^{59}$

\section{A. The Common-Law Analogy}

List's incorporation of reliance into antifraud jurisprudence likely puzzles tort scholars. Duty is an overarching concern in the development of tort law. For example, an individual is not responsible to a plaintiff for his own negligent act or omission unless the individual owes the plaintiff a duty to act with reasonable care. To determine if the individual is responsible for harm caused by negligence, courts inquire whether, under the circumstances, it was foreseeable that an act or omission negligently committed would have harmed the plaintiff. Reliance performs a similar function for the tort of misrepresentation. One well-reasoned perspective is that reliance defines the tort of misrepresentation at common law, so whether the plaintiff relied on the defendant's false representation does more than define who might recover. ${ }^{60}$ Reliance, in fact, defines the defendant's duty to speak truthfully, since tort law limits the defendant's duty not to misrepresent to those who are either in privity with the defendant or whose actual reliance could be foreseen. ${ }^{61}$

56. 340 F.2d 457 (2d Cir. 1965), cert denied sub nom., List v. Lerner, 382 U.S. 811 (1965). There are, of course, much earlier references to reliance in private litigation under the antifraud provision. See, e.g., Speed v. Transamerica Corp., 99 F. Supp. 808, 833 (D. Del. 1951) (allowing suit to proceed because all members of the class relied on the defendant's misrepresentations).

57. List, 340 F.2d at 462 . In taking this position, the court liberally invoked the Restatement of Torts as well as the leading treatises by Prosser and Harper. Id.

58. Id. at 463 .

59. Id. at $464-65$. (2006)

60. John C.P. Goldberg et al., The Place of Reliance in Fraud, 48 ARIZ. L. REV. 1001, 1002-03

61. See RESTATEMENT (SECOND) OF TORTS $\$ 531$ (1977) (stating that a tortfeasor is liable for damages resulting from "justifiable reliance in the type of transaction in which he intends or has reason to expect their conduct to be influenced" (emphasis added)); see, e.g., Hafen v. Strebeck, 338 F. Supp. 2d 1257, 1265 (D. Utah 2004) (interpreting Minnesota precedent to determine that parties 
In contrast to the common-law action of misrepresentation or deceit, the duty not to engage in material misrepresentations is clearly and broadly set forth in Rule 10b-5. The duty exists without evidence of reliance. Thus, an SEC enforcement action is successful without proof that any investors relied on the misrepresentation. The violation is complete upon showing that a material omission or misstatement was committed in connection with the purchase or sale of a security. Because reliance under securities laws serves a function other than defining the duty the defendant owes the plaintiff, it should enjoy a role distinct from causation in common-law torts. But what is that role?

An important qualification to the above analysis springs from considering what interests the antifraud provision should protect. That is, just why is it within the purpose of the antifraud rule to reach a particular material omission or misstatement? More specifically, is evidence of reliance a necessary component for assuring that the interest protected by the antifraud provision is fulfilled in the particular case? At the granular level, a material misrepresentation interdicts a basic value of the securities laws, namely that of enabling full and fair disclosure to investors. The reasons for seeking this goal are multiple 62 and, at the level of a single "classic" investor, easy to defend: a material misrepresentation that induces an investor to trade at a price she would not otherwise have believed reasonable has harmed that investor. Absent evidence that an investor's decisionmaking is actually impaired,

engaged in arms-length, commercial transactions owe no duty of care for negligent misstatements but do owe a duty of honesty, defined as "an inherent duty to be honest and not state intentional misrepresentations”); In re Enron Corp. Sec., Derivative \& ERISA Litig., 235 F. Supp. 2d 549, 60406 (S.D. Tex. 2002) (holding that Texas law makes defendants liable for misrepresentation when making false or misleading statements that create reliance in others in privity of contract with the defendant or others about whom the defendant has information concerning an "especial likelihood" that the party will rely on the tortfeasor's statement); Consol. Oil \& Gas, Inc. v. Ryan, 250 F. Supp. 600, 607 (W.D. Ark. 1966) (stating that Arkansas law recognizes that vendor/purchaser parties with a long-term and trusting relationship owe each other a "duty of honesty" when a specific request for information is made, any violation of which can constitute fraud or deceit independent of a fiduciary relationship); Woodward v. Dietrich, 548 A.2d 301, 311-16 (Pa. Super. Ct. 1988) (holding that a contractor who engaged in misrepresentation could be liable to future buyers of a house who were not in privity of contract with the contractor but who foreseeably suffered from harm resulting from the contractor's misrepresentation to a previous buyer); Ernst \& Young, LLP v. Pac. Mut. Life Ins. Co., 51 S.W.3d 573, 578-82 (Tex. 2001) (holding that despite Texas's unusually phrased law concerning reliance, misrepresentors are liable in tort for damages resulting from reliance by parties in privity of contract or parties about whom the misrepresentor has information concerning an "especial likelihood" that the party will rely on the tortious statement, consistent with the "reason to expect" language in section 531 of the Second Restatement of Torts).

62. See James D. Cox, Coping in a Global Marketplace: Survival Strategies for a 75-Year Old SEC, 95 VA. L. REV. 941, 959-61 (2009) (listing as objectives sought by disclosure and antifraud provisions identifying capital allocation, facilitating investor decisionmaking, deterring fraud, and disciplining managers). 
there is no cause to believe that the hallowed objective of full and fair disclosure was violated. Thus, reliance by the investor on the misrepresentation closes the circle and underscores the policy served by according that investor standing to sue for conduct inconsistent with the antifraud provision. ${ }^{63}$

But the illustration is quaint. A good deal of investment behavior is driven by decisions unrelated to a particular kernel of material information. For example, a financial institution's decision to purchase may be due to portfolio rebalancing arising from its obeisance to an indexing strategy. Or consider the lay investor who purchases the shares of an industry leader based on financial reports that the particular industry should do well in the forthcoming fiscal period. ${ }^{64}$

In light of the wide range of possible investor behavior, the focus of the antifraud provision should not be limited to protecting investor decisionmaking in the narrow context of non-open market-trading venues; certainly discriminating among such different approaches to investing appears hard to justify if each approach is, to some extent, guided substantially by faith in the overall integrity of that market. Because a violation exists without demanding evidence that investor judgments were adversely affected by the misrepresentation, at least in SEC enforcement actions, the conduct does not become less of a violation or less harmful to the investor if the complainant is a private party who did not rely on the material misrepresentation itself. Thus, in the open market context, securities laws should at least serve the more generalized objective of assuring investors that the markets are not rigged or otherwise populated by fraudulent information. This observation appears vital to Justice Blackmun's discussion of the role presumptions play in the resolution of disputes-advancing a public interest such as maintaining the integrity of capital markets. ${ }^{65}$

To be sure, there is intuitive appeal to the idea that defendants in private suits should not be financially responsible for having made a materially false statement if that statement played no role in the plaintiff's loss. This concern reflects an understanding of reliance. That

63. See, e.g., Jill E. Fisch, The Trouble with Basic: Price Distortion After Halliburton, 90 WASH. U. L. REV. 895, 895, 912, 914 (2013). Professor Fisch wisely observes that, in its traditional appearance, securities fraud was proscribed to protect "the autonomy of the investment decision" so that investors "are not deceived into trading." Id. at 914, 916. With a focus on price, which occurs in fraud on the market, the focus shifts to protecting investors who seek to "trade at a price undistorted by fraud." Id. at 914. The point of this Article is that each fits within the purpose of the antifraud provision, but that the means to establishing causality is different with reliance serving the former and is not necessary in the latter. Reliance therefore is a tool, not an objective.

64. See, e.g., Panzirer v. Wolf, 663 F.2d 365, 366 (2d Cir. 1981), vacated as moot sub nom., Price Waterhouse v. Panzirer, 459 U.S. 1027 (1982).

65. Basic Inc. v. Levinson, 485 U.S. 224, 245 (1988). 
is, reliance, at least in the one-on-one situation where the plaintiff deals directly with the defendant, serves the critical function of linking the plaintiff's economic loss to the defendant's misconduct. In this context, the investors' reliance supports both that the statute's purpose was violated and that the violation induced the plaintiff's trade. It does not, however, make the case that the trade caused financial harm to the relying investor. More would need to be established before the defendant is required to compensate the investor for the harm suffered by relying on the defendant's misrepresentation. This is as it should be. Causality is an inherent and desirable element in private litigation. Reliance can be seen as one means to establish part of the required causality but not as the sole means for establishing causation or for linking the defendant's violation with the plaintiff's injury. So viewed, reliance is part of the causation inquiry. Basic and now Amgen invites consideration of whether reliance is a meaningless cog in the causation wheel when fraud is perpetrated impersonally on an open market.

\section{B. Causation Is Context Specific}

It is important for causality to be independently determined in securities fraud suits. That is, requiring proof of reliance or establishing causation does not render materiality superfluous. The standard for materiality is not conditioned on the defendant's omission or misstatement impacting the plaintiff's, or for that matter anyone else's, investment decision. The test for materiality, first announced by the Supreme Court in the context of proxy-statement omissions, "does not require proof of a substantial likelihood that disclosure of the omitted fact would have caused the reasonable investor to change his vote."66 Rather, materiality requires "a showing of a substantial likelihood that, under all the circumstances, the omitted fact would have assumed actual significance in the deliberations of the reasonable" investor or shareholder. ${ }^{67}$

This formulation necessarily means that there are many facts that can be material under the circumstances but would not have changed the investors' decision to trade at a particular price, had they been disclosed. It is this mismatch between materiality and causality that produces so much of the tension around the scope of fraud on the market. Fraud on the market does relax the inquiry into causality by dispensing with individual inquiries into investor reliance and, thus, can place more weight on the broader standard of materiality. The

66. TSC Indus., Inc. v. Northway, Inc., 426 U.S. 438, 449 (1976).

67. Id. 
application of fraud on the market can be tweaked to address this problem of overinclusive recoveries. However, limiting fraud on the market to securities traded in markets with certain characteristics (e.g., market capitalization and number of analysts) does not address the problem at all. On the other hand, evidence that a security's price moved following the release of the allegedly false announcement or the correction of an earlier false announcement demonstratively addresses the disconnect that otherwise exists between materiality and causality.

Were materiality to serve the dual purposes of guiding whether omissions or misstatements are actionable as well as laying the foundation for proving causation, the standard would be inherently overinclusive. Under the Court's analysis, a fact is material irrespective of whether its omission or misstatement actually changes the investor's decision, so long as there is a substantial likelihood that the fact would have assumed actual significance in the reasonable investors' deliberations. Proof of reliance by the investor moves the inquiry into the representation's causative impact. The reliance element is necessary when a piece of information may be significant to an objectively qualified investor but, due to a variety of unique circumstances, does not assume actual significance to the plaintiff in a particular case. Some additional filter is therefore needed because the plaintiff's circumstances may not match the objective standard of the reasonable investor. More likely, the omitted or misstated fact may not have been so probative as to alter the plaintiff's investment decision from what it would have been had there been no omission or misstatement. Thus, a robust inquiry into the plaintiff's reliance overcomes the overbreadth of the materiality standard. In this way, reliance links the violation with the plaintiff's loss. That is, reliance is truly a means for determining causality. The allegation of reliance, however, is not the only method for establishing causation.

The preceding view of reliance is consistent with the Court's holding in Affiliated Ute Citizens v. United States, which reversed the circuit court's dismissal of the action because the investors failed to establish their reliance. 68 The Court succinctly reversed the lower court, holding that " $[\mathrm{u}]$ nder the circumstances of this case, involving primarily a failure to disclose, positive proof of reliance is not a prerequisite to recovery. All that is necessary is that the facts withheld be material . ..." 69 To many lower courts and commentators, Affiliated Ute assigns double duty to the element of materiality; they believe that

68. 406 U.S. 128, 152-53 (1972), aff'g in part, rev'g in part Reyos v. United States, 431 F.2d 1337 (10th Cir. 1970).

69. Id. at 153. 
proof of materiality establishes both the importance of the alleged misrepresentation and that the misrepresentation assumed sufficient significance to establish that it induced the plaintiff to trade. This conclusion not only ascribes too limited significance to the qualifier "under the circumstances of this case" but also overlooks the facts before the Court. The Affiliated Ute plaintiffs were unsophisticated, the defendants unquestionably stood in a position of trust to the plaintiffs, the defendants had a backlog of eager buyers for the shares at prices substantially above the price at which the plaintiffs sold their shares to the defendants, and the defendants garnered enormous profits through their representation of the plaintiffs. ${ }^{70}$ Thus, Affiliated Ute's egregious facts far more persuasively establish causation than would a hypothetical inquiry into the plaintiff's reliance on an event that never occurred. This raises the question whether causality is only resolved by reliance. Affiliated Ute's unique facts, and the Court's reference to "under the circumstances of this case," clearly support the view that causation can be addressed in multiple ways.

\section{Causation in Collective Decisionmaking}

In the corporate setting, many decisions are the composite of individual decisions of shareholders. Thus, acquisitions, amendments to articles, and even dissolution involve securities transactions for which private suits are available when they are accompanied by material misrepresentations. In Mills v. Electric Auto-Lite Co., the Court confronted how causation is addressed within the setting of group decisionmaking. ${ }^{71}$ The Court concluded, albeit generally, that causation is established by proof that "the proxy solicitation itself, rather than the particular defect in the solicitation materials, was an essential link in the accomplishment of the transaction."72 The essence of this test is that causation exists when the soliciting defendant lacks sufficient voting power to approve the transaction solely by voting the shares controlled by the defendant. ${ }^{73}$ The Court reasoned that this approach avoided the

70. Id. at 145-47. In TSC Industries, the Court defined materiality for the first time. 426 U.S. at 449. In doing so, the Court expressly rejected the looser standard that the misrepresentation "might" assume significance to the reasonable investor. Id. at 445-47. In dicta, Affiliated Ute invoked the "might" standard. 406 U.S. at 153-54. As seen, TSC Industries unhinged the materiality test from the misrepresentation's ultimate impact on the plaintiff's decision to buy, sell, or vote. 426 U.S. at 449 .

71. 396 U.S. 375,379 (1970)

72. Id. at 385 .

73. See, e.g., Va. Bankshares, Inc. v. Sandberg, 501 U.S. 1083, 1106, 1108 (1991) (finding causation missing where defendant's ownership far surpassed the percentage needed to assure approval of the company's sale based on materially misleading proxy solicitation); Mills, 396 U.S. 
difficulties of determining how many votes were affected by the material omission or misstatement; any doubt regarding the misrepresentation's probable impact on stockholder voting is better resolved in favor of voting shareholders-the group Congress intended to be the beneficiary of the regulatory provision. ${ }^{74}$

Shareholder voting decisions are collective because the will of the majority binds the many. Even the extraordinary stockholder who knew-through resourcefulness, blind luck, or unique talents-that the circulated proxy statement was misleading, and therefore voted against the resolution, is bound by the result if the transaction is nonetheless approved. Thus, even though the materially misleading proxy statement did not interfere with that stockholder's voting decision, it nonetheless was the causal link to the harm befalling the nonduped shareholder. Mills shows how aggregations of individual actors not only make group decisions, but also suffer as a group. Whether the voting shareholder relied or did not rely in this context does not make the harm greater or smaller.

Mills demonstrates that the inquiry into causality is not only more encompassing than the inquiry into reliance, but that reliance itself can be irrelevant in establishing causation. When it comes to causality, as the Court emphasized in Affiliated Ute, the circumstances not only matter, they matter a lot.

Embracing the framework that causation is established by evidence that the misrepresentation distorted the security's price creates a clean path forward for clarifying Basic. This would effectively render all members of the class price takers rather than pricemakers without focusing on their role in "making" the price. As price takers, investors would be analogous to the proxy voters in Mills, where the Court held it was neither practicable nor desirable to inquire into whether each voting stockholder had been duped by the omission. It was sufficient that the defendant lacked enough votes to assure approval of the merger. A price-distortion method of interpreting fraud on the market could build on this approach. The approach would require reorienting Basic and now Amgen from its emphasis on investor reliance on the pricing process for the securities to whether the price itself had been affected. Nonetheless, it is more consistent with Basic and Amgen to remain focused on whether the security's trading characteristics are consistent with presumptions regarding investors' reliance on the trustworthiness of the market in which the security was

at $385 \mathrm{n} .7$ (expressing uncertainty as to whether causation would be an essential link where the defendant held sufficient voting power to approve the transaction for which proxies were solicited). 74. Mills, 396 U.S. at 1104-06. 
traded. To be sure, evidence of price distortion would be probative of how the security's prices responded to publicly available information. But other information would also be at hand to support or reject assertions that investors relied on the integrity of that security's market.

\section{AMGEN'S CLARIFICATION}

Amgen presents an example of how the contemporary construction of the antifraud provision pleases neither of the combatants in securities class action suits. The Amgen class was composed of investors who purchased Amgen shares during a period when Amgen allegedly made several material misrepresentations regarding two of its major pharmaceutical products, Epogen and Aranesp. ${ }^{75}$ There were two issues before the Court. First, as a condition of class certification, should the plaintiffs be required to establish the materiality of the alleged misrepresentations? ${ }^{76}$ Second, should the defendant be accorded the opportunity to rebut the assertion of materiality by showing that the truth behind each of the alleged misrepresentations had already entered the marketplace? ${ }^{77}$ Defendants predictably wanted these issues to be part of the class certification decision so as to reduce the hydraulic pressure that class certification places on settlement even though those issues were unresolved. ${ }^{78}$ Correlatively, the plaintiffs naturally preferred fewer substantive determinations in the all-critical certification stage. ${ }^{79}$

Amgen's significance does not lie in how it resolved these opposing tugs. As examined more closely below, four justices joined Justice Ginsburg's opinion, which held that a finding on the merits of any substantive element of the antifraud suit is not a precondition to class certification. ${ }^{80}$ To the Amgen majority, courts deciding whether to certify the class should only examine whether common questions of law and fact predominate, so that their collective resolution makes a class action the appropriate procedural mechanism. ${ }^{81}$ The majority ruled that conditioning certification on proof of the alleged misrepresentation's materiality would put the cart of substantive adjudication before the

75. A full narrative of the facts appears in Connecticut Retirement Plans and Trust Funds $v$. Amgen Inc., 660 F.3d 1170, 1172-73 (9th Cir. 2011), aff'd, 133 S. Ct. 1184 (2013).

76. Amgen Inc. v. Conn. Ret. Plans \& Trust Funds, 133 S. Ct. 1184, 1191 (2013).

77. Id. at 1203 .

78. Id. at 1191, 1203.

79. Id.

80. Id. at 1191 .

81. Id. 
horse of procedure. ${ }^{82}$ Justice Alito concurred, but did so by expressing his interest in revisiting the substantive theory on which common questions in securities fraud claims depend-the fraud-on-the-market presumption of market causation. ${ }^{83}$ Less cautious than Justice Alito were the three dissenters who believed the Court should revisit Basic's embrace of fraud on the market. ${ }^{84}$ Thus, Amgen houses the dog that would not bark - the continuing vitality of the securities class action.

Amgen did not, as some had hoped, depart from the "reliance" rhetoric. ${ }^{85}$ Furthermore, it repeatedly references "efficient" 86 and "efficiency" 87 when describing the instances in which the fraud-on-themarket approach to causation is applicable. The references are, therefore, more specific than Basic's plurality, which more generally referred to "well-developed" markets. ${ }^{88}$ What distinguishes Amgen is the majority's gloss on their use of "efficient" and "efficiency." They invoked these terms to describe the natural incorporation of financially significant information into security prices. ${ }^{89}$ Therefore, Amgen's significance rests on the move from this observation to conclude that most investors "rely on the security's market price as an unbiased assessment of the security's value in light of all public information."90 Missing in Amgen is the emphasis present in Basic that the critical reliance is that of investors on the market; in Amgen, there is a subtle shift away from some markets having characteristics that attract investors' reliance on security prices to a broader view where the focus is on the pricing process and not the market itself. Moreover, Amgen does not require that the security historically reflected all material public information as a condition of market efficiency. Instead, the majority recognized that a security can be deemed traded in an efficient market if its shares "generally" reflect publicly available information. Amgen offers the following explanation of how the fraud-on-the-market presumption is justified:

This presumption springs from the very concept of market efficiency. If a market is generally efficient in incorporating publicly available information into a security's market price ... it is reasonable to presume that most investors-knowing that they have little hope of outperforming the market in the long run based solely on their analysis of publicly

82. Id.

83. Id. at 1204 (Alito, J., concurring).

84. Id. at 1216 (Thomas, J., dissenting).

85. See, e.g., Fisch, supra note 63, at 39 (observing that reliance is inconsistent with the efficient market hypothesis and therefore illogical in the context of market-based harm).

86. Amgen, 133 S. Ct. at 1188, 1192-93.

87. Id. at 1192,1199 .

88. Basic Inc. v. Levinson, 485 U.S. 224, 246-47 (1988).

89. Amgen, 133 S. Ct. $1192-93$.

90. Id. at 1192 . 
available information - will rely on the security's market price as an unbiased assessment of the security's value in light of all public information. Thus, courts may presume that investors trading in efficient markets indirectly rely on public, material misrepresentations through their "reliance on the integrity of the price set by the market." 91

Amgen, however, does not render price distortion a litmus test for fraud on the market's application;92 Amgen instead invites evidence of efficient pricing of the company's securities. The majority's sense of what constitutes efficiency is a market that regularly reflects publicly available information. This would appear to reject the lengthy list of criteria that lower courts have developed as the gateway for certifying a class based on fraud on the market. Simply stated, Amgen invites the testing of market efficiency through empirical observation, namely evidence of how a particular security's price has responded to financial announcements.

Additionally, Amgen establishes that a security can be traded in an efficient market even though that market does not always incorporate publicly available information into a security's price. Thus, Amgen rejects the numerous holdings in the circuit courts that condition fraud on the market on evidence that a firm's security regularly reflected all publicly available information. ${ }^{93}$ This rejection invites lower courts to consider how to rule when a security's price does not respond to financially significant information: is the absence of observable price movement evidence that the market is inefficient or that an efficient market is documenting the immateriality of the information? Amgen also notes that not all investors harbor the same belief regarding the futility of earning above average returns by trading on public information. In all respects, Amgen moves the framework of fraud on the market closer to what is supported by the efficient market literature.

91. Id. at 1192-93 (emphasis added) (quoting Basic, 485 U.S. at 245). Central to Amgen's holding was Amgen's concession that the alleged misrepresentations were public and that its securities traded in an efficient market, so that "the market for Amgen's securities promptly digested current information regarding Amgen from all publicly available sources and reflected such information in Amgen's stock price." Id. at 1193.

92. Professor Donald Langevoort reports that at least Justice William Brennan, part of the thin plurality opinion, preferred a more permissive approach to causation where proof that the misrepresentation distorted the security's price established causation without inquiry into any form of investor reliance. Donald C. Langevoort, Basic at Twenty: Rethinking Fraud on the Market, 2009 Wis. L. REV. 151, 157 \& n.25. Amgen would appear not to change the result in GAMCO Investors, Inc. v. Vivendi, S.A., Fed. Sec. L. Rep. (CCH) 9 97,306 (S.D.N.Y. 2013) (dismissing a claim where the security's price, even though distorted by fraudulent statements, assumed no importance in the investment model used by the investor).

93. See supra note 34 . 


\section{SCALIA'S NEAR HIT}

Justice Scalia, separately dissenting, offers an intriguing interpretation of Basic. Rather than denying any access to fraud on the market, he and the other dissenters would require evidence of materiality for certification of the class, reasoning that Basic itself premised its presumption on investors' presumed reliance on the security's price being impacted by a material misrepresentation. ${ }^{94}$ Justice Scalia's reasoning bears some promise for how courts can handle fraud-on-the-market suits in the future.

Presumably, Justice Scalia would have upheld class certification if the plaintiffs in Amgen alleged that the defendant's various announcements produced an observable price increase. Similarly, Justice Scalia would have found comfort in Basic's certification because the alleged facts showed that each of the three denials was accompanied by an observable price drop in Basic's share prices. The plaintiffs, however, alleged neither of these scenarios in Amgen, most likely because there was no observable price adjustment. Indeed, the factual configuration of each is similar to that of PolyMedica. Each involves a disclosure alleged to be materially misleading without confirming any change in the issuer's operations or situation. For example, Basic falsely confirmed there would be no value-increasing merger, and Amgen confirmed its product was safe. Each, like PolyMedica, offered reassurance that past would be prologue as the nondisclosure confirmed already-held expectations by investors. In precisely these situations, observing market movement is nearly impossible. There, the Court's earlier decision in Dura Pharmaceuticals $v$. Broudo ${ }^{95}$ plays an important role.

In Dura, the Court held that in order to survive a motion to dismiss, the complaint must do more than broadly allege that a material misrepresentation inflated a security's price; the plaintiff must allege loss causation with particularity (i.e., that an observable price correction occurred upon release of the correct information). As a result, stock-price movement assumes significance in fraud-on-themarket cases, since allegations of price movement following a corrective disclosure provide prima facie support of loss causation. At the same time, a price-correction allegation can also support assertions that an earlier misstatement or omission was indeed material. Thus, even

94. 133 S. Ct. at 1205 (Scalia, J., dissenting).

95. 544 U.S. 336, 346 (2005). 
though Amgen and Erica P. John Fund v. Halliburton ${ }^{96}$ rejected the necessity of corroboration for class certification, an empirical inquiry into price correction can resolve whether the security traded in a market whose properties for that type of announcement are sufficient to justify Basic's presumption of investor reliance. ${ }^{97}$

Therefore, what may separate Justice Scalia from the Amgen majority is disagreement over the time at which evidence of stock-price movement should be interjected into the suit. The majority believes requiring proof of materiality as a condition to certification places the resolution of a central factual element into the pretrial stage, the certification of the class; the majority believed proof of this element was common to all members of the class. At the same time, the Court's decision in Dura requires that a complaint set forth facts establishing loss causation in order to survive a motion to dismiss. Thus, pursuant to Dura, Amgen should have been dismissed if all the complaint alleges is that Amgen's false statements caused its price to increase but failed to allege any price correction following Amgen's later corrective announcement.

With these potential scenarios in mind, is more at stake in Amgen, and earlier in Halliburton, than the procedural question of whether materiality and loss causation must be addressed via a motion to dismiss or as conditions for class certification? Each procedural rule poses a burden on the plaintiff at the pleading stage. If Amgen and Halliburton had each been decided differently, the burden confronting the plaintiff would have been more formidable; the standard would require that a preponderance of the evidence support the claim of materiality and loss causation, consistent with what courts have done on other class certification issues (e.g., whether the security was traded in an efficient market). Should the choice be influenced by whether the class certification decision occurs only after resolution of motions to dismiss and summary judgment?

Each party likely seeks an early decision on certification of the class. With the class certified, even preliminarily, the plaintiff enjoys the hydraulic pressure that decision places on the defendant to settle.

96. Erica P. John Fund, Inc. v. Halliburton Co., 131 S. Ct. 2179, 2186 (2011) (holding Fifth Circuit erred in requiring evidence of loss causation as a condition to certifying the class). The Court, similar to the Court in Amgen, stressed that loss causation, unlike reliance, does not implicate commonality. Therefore, the inquiry into loss causation is not germane to class certification.

97. The Ninth Circuit reached a very curious result in Miller v. Thane International, Inc., holding that although the market for the defendant company's stock was not efficient per the Cammer standards, nonetheless the absence of stock-price change upon revelation of the truth established the absence of loss causation. 615 F.3d 1095, 1103 (9th Cir. 2010). 
If the defendant prevails and the suit is not certified as a class, the suit disappears; if the defendant loses on class certification, it can still retain hope that its other pretrial motions will be successful. Moreover, the defendant enjoys another strategic advantage by advancing class certification before other pretrial motions: until all pretrial motions are resolved, the plaintiff does not enjoy discovery rights, so that in doing battle on many issues that can be in dispute for class certification, the plaintiff could have much less information than if the contest over class certification followed all the pretrial motions. In a nondisclosure case, the absence of discovery could hinder the plaintiffs' ability to identify when the defendant became aware of certain information. This knowledge would have helped plaintiffs' experts isolate probable impact of disclosures on a security's price in order to demonstrate the informational efficiency of the market.

Therefore, there is less distance separating Justice Scalia from the Amgen majority than meets the eye, assuming each camp is willing to look holistically at the facts. Why should a factual allegation about loss causation that is sufficient to survive a motion to dismiss not also be probative of the alleged materiality for class certification? Procedurally, the allegations in the complaint are tested on the assumption that they are correct. Therefore, the motion to dismiss tilts favorably toward the plaintiff. By contrast, the plaintiff does not enjoy deference in factually intensive class certification hearings. But, if the class certification hearings occurred after ample opportunity for discovery, a fuller examination of the suit would result. The plaintiffs' bar may prefer if the Amgen majority swung more toward Justice Scalia's perspective of Basic and focused on price distortion, instead of a poorly conceived assessment of market efficiency and a conditional presumption of reliance. Nonetheless, Amgen's repeated references to "efficient" and "efficiency" and the Amgen majority's view that these expressions refer to stocks that trade in informationally efficient markets cabin fraud on the market to such markets rather than on a bare showing of price distortion itself. This formulation thus invites a more probing inquiry of whether the trading in that security likely would be impacted by information alleged to be misstated or omitted, not just of narrow features of the individual security's market.

The Court's earlier decision in Eisen v. Carlisle \& Jacquelin proves instructive on this point. ${ }^{98}$ Eisen involved a securities class action with approximately six million class members. After a hearing, the district court accepted the plaintiff's position that notice to members

98. Eisen v. Carlisle \& Jacquelin, 417 U.S. 156, 177-78 (1974), aff'g 479 F.2d 1005 (2d Cir. 1973), rev'g 54 F.R.D. 565, 573 (S.D.N.Y. 1972). 
of the class could be provided by publication and assigned ninety percent of the notice cost to the defendants based on its finding that the class would likely prevail on the merits. ${ }^{99}$ The circuit court reversed the ruling, 100 and the Supreme Court affirmed the circuit's decision, reasoning as follows:

\begin{abstract}
We find nothing in either the language or history of Rule 23 that gives a court any authority to conduct a preliminary inquiry into the merits of a suit in order to determine whether it may be maintained as a class action. Indeed, such a procedure contravenes the Rule by allowing a representative plaintiff to secure the benefits of a class action without first satisfying the requirements for it. He is thereby allowed to obtain a determination on the merits of the claims advanced on behalf of the class without any assurance that a class action may be maintained. ${ }^{101}$
\end{abstract}

Importantly, both the circuit and Supreme Court decisions rejected a hearing that focused on the suit's merits. The Supreme Court emphasized that a preliminary hearing on the merits could prejudice the case against the defendant since such a hearing likely would not be accompanied by traditional rules of evidence and procedure. ${ }^{102}$ However, it is consistent with Eisen to have such a hearing focus on issues relevant to class certification, ${ }^{103}$ such as whether the particular security traded in an informationally efficient market. ${ }^{104}$ That is, Eisen does not foreclose lower courts from merit-based-like findings that link to whether the suit meets Rule 23's criteria for class certification. Indeed, hearings today are regularly held and evidentiary findings are made when class certification depends on whether a security traded in an efficient market such that the suit can be maintained on a fraud-onthe-market theory. This occurs even though there may well be

99. 54 F.R.D. at 573.

100. 479 F.2d at $1015-16$.

101. 417 U.S. at $177-78$.

102. Id. at 178 .

103. See, e.g., Gen. Tel. Co. of Sw. v. Falcon, 457 U.S. 147, 160 (1982) (stating that "sometimes it may be necessary for the court to probe behind the pleadings before coming to rest on the certification question," even though such a determination "generally involves considerations that are 'enmeshed in the factual and legal issues comprising the plaintiff's cause of action' " (quoting Coopers \& Lybrand v. Livesay, 437 U.S. 463, 469 (1978))); see also Wal-Mart Stores, Inc. v. Dukes, 131 S. Ct. 2541, 2552 \& n.6 (2011) (reaffirming the holding of Falcon, but clarifying that the Court found "nothing in . . Rule 23 ... gives a court any authority to conduct a preliminary inquiry into the merits of a suit in order to determine whether it may be maintained as a class action").

104. See In re Initial Pub. Offerings Sec. Litig., 471 F.3d 24, 41-42 (2d Cir. 2006) (holding that the trial judge is responsible for making factual findings about whether conditions for fraud on the market have been satisfied); Gariety v. Grant Thornton, LLP, 368 F.3d 356, 369 (4th Cir. 2004) (reversing district court for failing to inquire beyond factual allegations in complaint to determine whether there was sufficient basis to invoke fraud on the market). See generally Patricia Groot, Note, Fraud on the Market Gets a Minitrial: Eisen Through In re IPO, 58 DukE L.J. 1143, 1166 (2009) (showing that the holdings in Eisen and Falcon allow courts to consider relevant factual issues in making a decision on class certification). 
important overlaps between factors relevant to such a class certification determination and issues bearing on the ultimate merits of the suit. What has changed in Amgen is clarification by the Amgen majority that investor reliance is presumed where the market is informationally efficient, which, as reasoned here, is a condition that can and should be determined through empirical observation.

\section{CONCLUSION: MATCHING THE APPROACH WITH TODAY’S MARKETS}

Basic projected how reasonable investors are presumed to behave based on a hypothesis of how securities markets perform. While it did so on the infant base of literature supporting the efficient market hypothesis, it also justified the presumption more traditionally, anchored in "fairness, public policy and probability, as well as judicial economy." 105 The world has moved on since that presumption was first formulated.

For example, institutional investors who owned about twentyfour percent of public firms' equities in 1980 owned seventy percent in 2010. The typical NYSE-listed company had about fifty-four institutional holders in 1980; now such firms have 405 institutional shareholders. As assets have aggregated, passive management of funds has grown more common. Thus, more than one-third of total mutual fund and exchange traded fund assets are passively managed. ${ }^{106}$ Indeed, the average annual growth of passive assets promoted through mutual funds and exchange-traded funds has been twenty-six percent, compared to just thirteen percent for actively managed funds. ${ }^{107}$ This rapid movement toward passive investment, namely through indexing strategies, is mirrored by changes occurring with other institutional investors. For example, the giant pension fund CalPERS has invested more than one-half of its $\$ 255$ billion portfolio in passive strategies and is actively considering a move to a totally passive portfolio. ${ }^{108}$

Aside from the overt move toward passive investing, there is growing evidence that herding exists among institutional investors,

105. Basic Inc. v. Levinson, 485 U.S. 224, 245 (1988).

106. A Steady Climb for Indexing, WALL ST. J., Apr. 8, 2013, at R1 fig.

107. Rodney N. Sullivan \& James X. Xiong, How Index Trading Increases Market Vulnerability, 68 Fin. ANALYSTS J. 70, 73 (2012).

108. Jason Kephart, Passive Investing: If It's Good Enough for CalPERS . . ., INVESTMENTNEWS (Mar. 24, 2013, 12:01 AM), http://www.investmentnews.com/article/ 20130324/FREE/130329970; see also Passive Equity Portfolios of 10 Large Pension Funds, PENSIONS \& INVESTMENTS (Mar. 25, 2013), http://www.pionline.com/gallery/20130325/ SLIDESHOW2/325009999 (listing percentages of passive investment for several large pension funds where the range for the top five for their equity portfolio was seventy-two to ninety-three percent). 
according to developed "style"-characteristics-favored sectors. Pursuant to this practice, money managers and individual investors view securities as part of a group having shared characteristics and not as individual items. Herding ensues when investors seek to mimic the returns garnered earlier by investors moving into a particular style or category of investment. As a consequence, investment decisions are not guided by the cash flows of the individual firm but rather the riskreturn profile of the group. ${ }^{109}$ Neither passive investing nor style investing defy the presumption as formulated in Basic because neither is centered on the price of the individual firm's security; rather, both strategies focus more generally on the overall integrity of securities markets. ${ }^{110}$

Basic's supposition that investors rely on the price of a particular security is quaint in light of the dramatic changes that have occurred in equity markets and investment strategies. When the Court revisits Basic, which appears likely, it should bear in mind that markets, and particularly trading strategies, have changed markedly since fraud on the market was first conceived. The changes in markets, especially the moves toward increasing amounts of passive investing, are a testament to investors' foundational belief that markets are fair. It is this presumptive fairness - and the facts that attract investors to have this belief - that should guide courts in deciding whether a trade in a particular security should enjoy the protection of fraud on the market because that security traded in a market that shared this broad investor belief. It is a belief more broadly based than the security's price; it is founded on assumptions of the pricing process itself. Of course, the Court could continue to adhere to the binary view that markets are either efficient or not efficient, as determined by a set of criteria divorced from empirical or theoretical support. Another option is to rid the courts of fraud on the market and thereby deprive most investors of the only means by which they can recoup funds lost due to fraud. Neither of these latter two approaches is as compelling as applying fraud on the market based on the assumptions that do, in fact, underlie investor engagement in public markets.

109. Nicholas Barberis \& Andrei Shleifer, Style Investing, 68 J. FIN. ECON. 161, 162 (2003). Some empirical evidence shows that style investing exists. See, e.g., Nicole Choi \& Richard W. Sias, Institutional Industry Herding, 94 J. FIN. ECON. 469, 486 (2009) (concluding that institutional investors engage in style investing in a "herding" pattern); Kenneth Froot \& Melvyn Teo, Style Investing and Institutional Investors, 43 J. Fin. \& QUANTITATIVE ANALYsis 883, 891 (2008) (showing that major institutional investors chase trends in investing).

110. It is not likely that vendors, particularly those with a fiduciary relationship to their beneficiaries and customers, could pursue an indexing strategy without a basic belief that securities prices are not significantly affected by fraud. 
The position advanced in this Article is that Amgen's clear embrace of informational efficiency as the cornerstone of fraud on the market rids the theory of its once-binary quality. Now, courts can fully examine the information processing capabilities of the market in which a security is traded. The objective of that examination is whether investor expectations that information of the type alleged to have been misleading would customarily be impounded in the security's price. If so, investor reliance would be presumed, so that the class could be certified pursuant to fraud on the market. 